\title{
HUBUNGAN TINGKAT PENGETAHUAN IBU TENTANG ISPA DENGAN SIKAP IBU TENTANG PENCEGAHAN PENULARAN ISPA PADA BAYI USIA 0-12BULAN DI PUSKESMAS PANDAAN
}

\author{
Nur Ainiyah ${ }^{1}$, Dwining Handayani ${ }^{2}$ \\ Universitas Nahdlatul Ulama Surabaya - J1 Smea 57 Surabaya \\ Email : ainiyahannuri@unusa.ac.id
}

\begin{abstract}
ISPA is a disease that often occurs in children, especially toddlers. One of the factors increasing cases of ISPA in Puskesmas Pandaan known from interviews, 8 out of 10 people do not understand about ISPA and the prevention it The purpose of this research was to determine the correlation between mother's knowledge on ISPA with attitude of the mother on the prevention of transmission of ISPA in babies ages 0-12 Months in Helath Public Pandaan. The research method is analytic correlation with a sample population of 84 and 30 at the health center Pandaan in mothers who have babies aged 0-12 months who suffer from respiratory diseases by purposive sampling technique. Collecting data using closed questionnaire. For analysis of Spearman Rank correlation calculation used by the $95 \%$ significance level $(\alpha \leq 0.05)$, if $\alpha \leq 0.05$, Hi accepted. The result showed the level of knowledge of mothers about ISPA either by $46.67 \%$ of respondents, the remaining $26.67 \%$ of respondents sufficient and less. The attitude of mothers on prevention of transmission ISPA is good by $46.67 \%$ of respondents, and the rest is not a good $40 \%$ of respondents and $13.33 \%$ of respondents to the attitude is not very good, and $r$ count $>r$ table $(0.365>0.364)$ with $\alpha$ of 0.05 . Then there is a significant relationship between the level of knowledge of mothers about ISPA with transmission prevention in infants aged 0-12 months, because with knowledge and a good attitude will have an impact on healthy behaviors. With good knowledge and attitudes expected of a mother ISPA transmission in infants aged 0-12 months in particular can be prevented by following a health education and consultation with health workers in order to avoid further complications
\end{abstract}

\begin{abstract}
Abstrak : ISPA adalah penyakit yang sering terjadi pada anak terutama usia balita. Salah satu faktor meningkatnya kasus ISPA di Puskesmas Pandaan diketahui dari hasil wawancara, 8 diantara 10 orang ibu menjawab tidak mengerti tentang ISPA dan pencegahannya. Tujuan penelitian ini adalah mengetahui hubungan tingkat pengetahuan ibu tentang ISPA dengan Sikap Ibu tentang Pencegahan Penularan ISPA Pada Bayi Usia 0-12 Bulan di Puskesmas Pandaan. Metode penelitianini adalah analitik korelasional dengan populasi 84 dan sampel 30 di Puskesmas Pandaan pada ibu yang mempunyai bayi usia 0-12 bulan yang menderita penyakit ISPA dengan teknik purposive sampling. Pengumpulan data menggunakan kuesioner tertutup. Untuk analisa hubungan digunakan perhitungan Spearman Rank dengan taraf signifikansi 95\% $(\alpha \leq 0,05)$, jika $\alpha \leq 0,05$ maka Hi diterima. Hasil penelitian didapatkan tingkat pengetahuan ibu tentang ISPA baik oleh $46,67 \%$ responden, sisanya $26,67 \%$ responden cukup dan kurang. Sikap ibu tentang pencegahan penularan ISPA adalah baik oleh $46,67 \%$ responden, dan sisanya tidak baik $40 \%$ responden dan $13,33 \%$ responden untuk sikap sangat tidak baik. Didapatkan hasil $r$ hitung $>r$ tabel $(0,365>0,364)$ dengan $\alpha 0,05$. Maka ada hubungan yang signifikan antara tingkat pengetahuan ibu tentang ISPA dengan pencegahan penularan ISPA pada bayi usia 0-12 bulan, karena dengan pengetahuan dan sikap yang baik akan berdampak pada perilaku sehat.

Dengan pengetahuan dan sikap baik dari seorang ibu diharapkan penularan ISPA pada bayi usia 0-12 bulan khususnya dapat dicegah dengan cara mengikuti pendidikan kesehatan serta berkonsultasi dengan tenaga kesehatan agar tidak terjadi komplikasi lebih lanjut.
\end{abstract}

Kata Kunci : Tingkat Pengetahuan Ibu, Sikap Ibu, Penularan ISPA 


\section{PENDAHULUAN}

Banyaknya ibu yang tidak mengerti dan kurangnya informasi yang diperoleh tentang ISPA akan berpengaruh terhadap meningkatnya kasus ISPA pada bayi atau balita. Oleh karena tidak satupun orang tua yang menginginkan anaknya jatuh sakit, meskipun anaknya sakit Infeksi Saluran Pernafasan Atas (ISPA). Sedini mungkin orang tua akan mencari cara atau pencegahan agar anaknya tidak terjadi komplikasi lebih lanjut.

Pada akhir 2015, diperkirakan kematian akibat pneumonia sebagai penyebab utama ISPA di Indonesia mencapai lima kasus diantara 1000 bayi atau balita. Pneumonia mengakibatkan 150.000 bayi atau balita meninggal tiap tahun, atau 12.500 korban perbulan, atau 416 kasus sehari atau 17 anak perjam, atau seorang bayi tiap 5 menit. Dengan tingginya angka kematian akibat pneumonia sebagai penyebab utamanya adalah ISPA yang berkepanjangan tentunya menjadi hal penting yang perlu diperhatikan khususnya pada anak-anak terutama balita. Penyakit ISPA lebih rentan menyerang pada anak-anak terutama bayi atau balita.

Dari hasil wawancara terhadap 10 orang ibu yang mempunyai anak pada usia balita tentang penyakit ISPA di Puskesmas Pandaan didapatkan 8 orang tidak mengerti tentang ISPA dan cara pencegahannya. Orangtua yang tidak mengerti kemungkinan disebabkan yaitu kurangnya pengetahuan ibu tentang ISPA dan informasi yang masih minim pada masyarakat tentang ISPA. Karena dengan pengetahuan yang baik diharapkan masyarakat bisa mengerti dan waspada terhadap penularan ISPA yang tergolong cepat dan beresiko fatal khususnya pada bayi usia 0-12 bulan, pada usia tersebut tingkat kekebalan belum sempurna dan mudah terjadi komplikasi, serta pada usia tersebut bayi masih sangat membutuhkan perhatian dari ibu. Selain faktor pengetahuan yang merupakan salah satu penyebab ketidaktahuan ibu tentang ISPA, masalah sikap juga memegang peranan penting secara tidak langsung dalam meningkatkan atau menurunkan insiden ISPA. Karena dengan sikap yang positif tentunya akan berakibat pada perilaku ibu yang mendukung kesehatan keluarga.

Setelah peneliti melakukan studi pendahuluan di Puskesmas Pandaan, jumlah penderita ISPA dalam 3 bulan terakhir mengalami kenaikan yang sangat signifikan terutama pada bayi usia 0-12 bulan. Berdasarkan buku laporan ISPA yang ada di register rawat jalan tercatat pada bulan Maret sebanyak 84 bayi usia 012 bulan menderita ISPA, bulan April 2016 penderita, sedangkan pada bulan Mei 2016 adalah 92 penderita. (sumber: register poli BP dan rawat jalan UGD tahun 2015). Dari uraian tersebut diatas jelas sekali terlihat kenaikan prevalensi penderita ISPA sangat signifikan, untuk itu diperlukan upaya pencegahan terhadap penularan ISPA.

Pencegahan pada penyakit ISPA bisa dilakukan berdasarkan beberapa kriteria, antara lain dengan peningkatan status gizi yang baik pada ibu dan bayi, membiasakan hidup sehat dan terbebas dari polusi lingkungan yang tidak sehat (Depkes RI, 2015). Peneliti berasumsi bahwa setelah diberikannya Health Education tentang pencegahan ISPA yang penyajiannya bisa lewat wawancara, penyuluhan, seminar ataupun kegiatan-kegiatan lain. Pengetahuan ibu tentang ISPA yang baik diharapkan pengetahuan dan sikap tentang pencegahan ISPA juga baik sehingga akan mengurangi jumlah penderita ISPA pada bayi karena pengetahuan ibu merupakan komponen penting dalam menentukan sikap (Notoatmodjo, 2015).

Berdasarkan fenomena di atas, maka penulis ingin mengetahui "Hubungan Tingkat Pengetahuan ibu tentang ISPA dengan sikap ibu tentang pencegahan penularan ISPA pada bayi usia 0-12 bulan di Puskesmas Pandaan" 


\section{METODE}

Desain penelitian ini menggunakan studi korelasional yaitu mengkaji hubungan antara variabel. Penelitian korelasional bertujuan mengungkapkan hubungan korelatif antar variabel. Hubungan korelatif mengacu pada kecenderungan bahwa variasi suatu variabel diikuti oleh variasi vanibbeludatiner $p$ (Nursalam, 2008)

Populasi dalam penelitian ini adalah seluruh ibu yang mempunyai bayi (0-12 bulan) yang menderita ISPA di Puskesmas Pandaan. Sampel adalah sebagian ibu yang mempunyai bayi (0-12 bulan) yang menderita ISPA di Puskesmas Pandaan yang dianggap memenuhi kriteria inklusi yaitu bersedia menjadi responden, Ibu yang mempunyai bayi (0-12 bulan) dengan ISPA, responden tidak mengalami gangguan jiwa, serta orang tua tinggal satu rumah dengan balita yang ISPA

Tehnik sampling dilakukan secara probability sampling dengan teknik simple random sampling dimana semua subyek mempunyai kesempatan yang sama untuk dijadikan sampel dengan cara acak. Variabel independent dalam penelitian ini adalah pengetahuan ibu tentang ISPA. dan Variabel dependen dalam penelitian ini adalah Sikap ibu tentang Pencegahan penularan ISPA.

Data dianalisis dengan menggunakan uji statististik korelasi dari Spearman yaitu korelasi tata jenjang (Rank - Difference Correlation) dengan tingkat kemaknaan $\alpha=0,05 . \mathrm{H}_{0}$ ditolak jika $\rho<\alpha$, asumsi ada Ada hubungan antara tingkat pengetahuan ibu tentang ISPA dengan sikap ibu tentang pencegahan penularan ISPA pada bayi usia $0-12$ bulan di Puskesmas Pandaan.

\section{HASIL PENELITIAN}

Karakteristik Responden Berdasarkan Usia
Tabel 1. Distribusi Frekuensi Responden Berdasarkan Tingkat Pengetahuan Ibu Tentang ISPA

\begin{tabular}{clcc}
\hline No & Kategori & F & Persentase \\
\hline 1. & Baik & 14 & 46,67 \\
2. & Cukup & 8 & 26,67 \\
3. & Kurang & 8 & 26,67 \\
\hline \multicolumn{2}{c}{ Jumlah } & 30 & 100 \\
\hline Sumber Penelitian 2015 & &
\end{tabular}

Berdasarkan tabel 1 didapatkan bahwa hampir setengahnya tingkat pengetahuan responden berdasarkan hasil jawaban kuesioner pengetahuan sebesar $(46,67 \%)$ sebanyak 14 responden dikategorikan baik, dan hanya sebesar $(26,67 \%)$ responden sebanyak 8 orang yang mempunyai pengetahuan dengan kategori cukup dan kurang.

Tabel 2 Distribusi Frekuensi Responden Berdasarkan Sikap Tentang Pencegahan Penularan ISPA

\begin{tabular}{clcc}
\hline No & Kategori & F & Persentase \\
\hline 1. & Sangat baik & 0 & 0,00 \\
2. & Baik & 14 & 46,67 \\
3. & Tidak baik & 12 & 40,00 \\
4. & Sangat tidak baik & 4 & 13,33 \\
\hline \multicolumn{2}{l}{ Jumlah } & 30 & 100 \\
\hline
\end{tabular}

Pada tabel 2 dapat diketahui bahwa sikap ibu tentang pencegahan penularan ISPA pada bayi usia 0-12 bulan, hampir setengahnya $(46,67 \%)$ responden sebanyak 14 orang sebagian besar mempunyai sikap dengan kategori baik, begitu juga dengan responden yang mempunyai sikap sangat tidak baik tidak ada satupun, sebanyak 12 orang responden $(40 \%)$ mempunyai sikap yang dikategorikan tidak baik, dan hanya sebesar $(13,33 \%)$ responden sebanyak 4 orang mempunyai sikap yang dikategorikan sangat tidak baik.

Tabel 3. Hasil Uji Analisis Tingkat Pengetahuan Ibu Tentang ISPA Dengan 
Sikap Ibu Tentang Pencegahan Penularan ISPA Pada Bayi Usia 0-12 Bulan.

\begin{tabular}{|c|c|c|c|c|c|c|c|}
\hline \multirow{3}{*}{$\begin{array}{l}\text { Kriteria } \\
\text { Sikap }\end{array}$} & \multicolumn{7}{|c|}{ Kriteria Pengetahuan } \\
\hline & \multicolumn{2}{|c|}{ Baik } & \multicolumn{2}{|c|}{$\begin{array}{l}\text { Cukup } \\
\text { Baik } \\
\end{array}$} & \multicolumn{2}{|c|}{$\begin{array}{c}\text { Kurang } \\
\text { Baik }\end{array}$} & \\
\hline & $\mathrm{F}$ & $\%$ & $\mathrm{~F}$ & $\%$ & $\mathrm{~F}$ & $\%$ & \\
\hline $\begin{array}{l}\text { Sangat } \\
\text { Baik }\end{array}$ & 0 & 0 & 0 & 0 & 0 & 0 & \\
\hline Baik & 8 & 26,67 & 5 & 16,67 & 1 & 3,33 & \\
\hline $\begin{array}{l}\text { Tidak } \\
\text { baik }\end{array}$ & 5 & 16,67 & 3 & 10 & 4 & 13,33 & 0,048 \\
\hline $\begin{array}{l}\text { Sangat } \\
\text { tidak } \\
\text { baik }\end{array}$ & 1 & 3,33 & 0 & 0 & 3 & 10 & \\
\hline
\end{tabular}

Berdasar tabel 3 di atas didapatkan bahwa sebesar $(26,67 \%)$ sebanyak 8 responden mempunyai pengetahuan dan sikap yang baik, sebesar $(16,67 \%)$ sebanyak 5 responden mempunyai pengetahuan yang baik dan sikap tidak baik, dan $(3,33 \%)$ sebanyak 1 responden mempunyai pengetahuan baik dan kategori sikap sangat tidak baik, sebanyak 5 responden (16,67\%) mempunyai pengetahuan yang cukup dan sikap yang baik, sebanyak 3 responden (10\%) mempunyai pengetahuan cukup dan mempunyai sikap sangat tidak baik, seperti tabel di atas responden yang mempunyai penetahuan yang cukup dan mempunyai sikap sangat tidak baik tidak ada satupun, begitu juga pada responden yang memunyai pengeahuan baik, cukup, kurang dan mempunyai sikap yang sangat baik tidak ada satupun, dan hanya 1 responden $(3,33 \%)$ mempunyai pengetahuan kurang dan sikap yang baik, dan sebanyak 4 responden (13,33\%) mempunyai pengetahuan kurang dan sikap tidak baik, dan sisanya sebanyak 10 responden $(10 \%)$ sebanyak 3 responden saja yang mempunyai pengetahuan kurang dan sikap sangat tidak baik.

Hasil penghitungan data dengan rumus korelasi spearman rank didapatkan hasil koefisen korelasi rank spearman 0,048 dengan taraf signifikan 0,05 atau 95\% dan didapatkan ada hubungan antara tingkat pengetahuan ibu tentang ISPA dengan sikap Ibu tentang pencegahan penularan ISPA pada bayi usia 0-12 Bulan.

\section{PEMBAHASAN}

1. Tingkat pengetahuan ibu tentang ISPA Dari data tabel 1 didapatkan bahwa 14 responden $(46,67 \%)$ memiliki pengetahuan yang baik, sedangkan sisanya yaitu 8 responden $(26,67 \%)$ memiliki pengetahuan yang cukup dan kurang. Hal ini mungkin disebabkan hampir hampir setengahnya responden $(46,67 \%)$ memiliki latar belakang pendidikan tingkat atas dan sumber informasi yang diperoleh (40\%) dari media elektronik dan petugas kesehatan.

Pengetahuan merupakan suatu proses belajar dengan menggunakan panca indera yang dilakukan oleh seseorang terhadap suatu objek tertentu untuk dapat menghasilkan pengetahuan atau keterampilan (Wilmar Tambunan, 1988 dalam buku Hidayat, 2008). Faktor-faktor yang mempengaruhi pengetahuan adalah umur pendidikan, intelegensia, sumber informasi, status social ekonomi serta pengalaman. (Latipun, 2008). sedangkan Herliansyah (2006), pengetahuan juga bisa didapatkan melalui pengalaman pribadi manusia yang terjadi berulangkali, jika seseorang memiliki pengalaman yang lebih maka menghasilkan pengetahuan yang lebih. Hasil penelitian pada ibu yang berpengetahuan yang baik didapatkan karena ibu sudah berpengalaman dalam mengasuh anaknya (mempunyai anak/ balita lebih dari 1) serta usia ibu (46,67\% berusia 26-30 tahun ). Hal ini juga menunjukkan bahwa usia mempengaruhi dalam memperoleh informasi yang lebih banyak secara langsung maupun tidak langsung.

2. Sikap ibu tentang pencegahan penularan ISPA pada bayi usia 0-12 bulan.

Dari data tabel 2 didapatkan bahwa hampir setengahnya 14 responden $(46,67 \%)$ mempunyai sikap dalam kategori 
baik dan dan hanya 12 responden (40\%) mempunyai sikap dalam kategori tidak baik, dan sisanya 4 responden $(13,33 \%)$ mempunyai sikap sangat tidak baik. Hal ini mungkin disebabkan hampir setengahnya responden $(46,67 \%)$ memiliki pengetahuan yang baik.

Sikap terdiri dari 3 komponen yang salah satunya komponen kognitif, dengan berkembangnya intelegensi, bertambahnya pengetahuan maka akan terbentuk sikap (Azwar, 2010). Dari pengalaman peneliti bahwa, sikap yang didasari pengetahuan, kesadaran, dan sikap yang positif akan lebih langgeng daripada sikap yang tidak didasari pengetahuan.

Pada umumnya ibu cukup mengetahui tentang penyakit ISPA, namun kadang kala mereka kurang menyikapi upaya-upaya untuk mencegah terjadinya penyakit ISPA. Kondisi ini disebabkan karena kurang memperhatikan upaya untuk hidup sehat dalam rangka menjaga, memelihara dan meningkatkan kesehatan sehingga dibutuhkan untuk hidup sehat dan bersih.

3. Hubungan antara tingkat pengetahuan ibu tentang ISPA dengan sikap ibu tentang pencegahan penularan ISPA pada bayi usia $0-12$ bulan.

Dari data tabel 3 didapatkan bahwa 8 resoponden $(26,67 \%)$ mempunyai sikap dan pengetahuan dalam kategori baik dan $(3,33 \%)$ mempunyai pengetahuan kurang dan sikap yang baik. Hal ini mungkin disebabkan oleh perbedaan tingkat pendidikan responden yang hampir setengahnya $\quad(46,67 \%) \quad$ responden berpendidikan terakhir SMA dan $(26,67 \%)$ berpendidikan terakhir Perguruan Tinggi, dan sisanya $(16,67 \%)$ responden pendidikan terakhir SMP dan sisanya (10\%) responden pendidikan terakhir SD, serta pengalaman pribadi, kebudayaan dan media massa dari masing-masing responden

Hasil perhitungan data dengan rumus korelasi Spearman Rank didapatkan hasil $r$ hitumg sebesar 0,365 dengan dan $p$ $=0,048(\mathrm{p}<\alpha)$ hipotesa alternatif diterima (Ha) ditentukan dan hipotesa nol (Ho) ditolak, artinya ada hubungan antara tingkat pengetahuan dengan sikap ibu tentang pencegahan penularan ISPA pada bayi usia $0-12$ bulan.

Semakin tinggi pendidikan seseorang maka semakin tinggi pula tingkat pengetahuan. Makin banyak pengetahuan yang didapat maka akan semakin baik pula sikap seseorang terhadap objek tersebut. Pengetahuan merupakan dasar utama seseorang untuk menentukan sikap baik positif maupun negatife. Sikap positif dapat berubah menjadi negatife bila tidak mendapat bimbingan dan sebaliknya karena sikap mempunyai valensi, maka sikap positif dapat juga ditingkatkan menjadi lebih positif (Notoatmodjo, 2015)

Hal ini sejalan dengan enelitian yang dilakukan oleh Intan (2014) mendapatkan bahwa terdapat hubungan antara pengetahuan ibu tentang penyakit ISPA dengan perilaku pencegahan ISPA pada balita didapat nilai $\mathrm{p}$ value $=0,022$, adanya hubungan antara pengetahuan ibu tentang penyakit ISPA dengan perilaku pencegahan ISPA dipengaruhi oleh beberapa faktor diantaranya faktor predisposisi yaitu pengetahuan ibu yang masuk dalam kategori kurang baik belum melakukan pencegahan dengan baik dan pengetahuan tentang ISPA masih minim. Sejalan pula dengan penelitian yang dilakukan oleh Dwi Yani Bidaya, Titan Ligita, Meta Trissya (2013) mendapatkan bahwa terdapat hubungan antara tingkat pengetahuan ibu terhadap perilaku pencegahan ISPA pada bayi didapat nilai $\mathrm{p}$ value $=0,00$, peneliti berasumsi bahwa kejadian ISPA dipengaruhi langsung oleh beberapa faktor antara lain : pengetahuan dan perilaku orang tua. Terlepas dari faktor pengetahuan dan perilaku, kondisi lingkungan (baik lingkungan di luar rumah maupun dalam rumah) juga mempengaruhi terjadinya ISPA. 
Peranan pengetahuan dalam membina sikap seseorang. Dalam teori dijelaskan pengetahuan akan membentuk tindakan atau perilaku seseorang, dalam kenyataan tidak semua pengetahuan yang baik akan mempunyai perilaku atau sikap yang baik. Tetapi kecenderungan untuk bersikap yang baik itu akan lebih tinggi dibandingkan dengan pengetahuan yang kurang dalam berkomunikasi

\section{SIMPULAN}

Berdasarkan hasil penelitian dan pembahasan "Hubungan Tingkat Pengetahuan Ibu Tentang ISPA Dengan Sikap Ibu Tentang Pencegahan Penularan ISPA Pada Bayi Usia 0-12 Bulan Puskesmas Pandaan Kabupaten Pasuruan" dapat diambil kesimpulan :

1. Pengetahuan ibu tentang ISPA di Puskesmas Pandaan Kabupaten Pasuruan hampir setengahnya didapatkan hasil adalah baik (46,67\%).

2. Sikap ibu tentang pencegahan penularan ISPA pada bayi usia 0-12 bulan hampir setengahnya adalah baik $(46,67 \%)$.

3. Ada hubungan yang signifikan antara tingkat pengetahuan ibu tentang ISPA dengan sikap ibu tentang pencegahan penularan ISPA pada bayi usia 0-12 bulan berdasarkan hasil analisa Spearman Rank didapatkan $r$ hitung sebesar 0,365 dengan taraf kepercayaan 95\% 0,364 ( $\mathrm{r}$ hitung $>\mathrm{r}$ tabel)

\section{DAFTAR PUSTAKA}

Azwar, Saifudin. (2010). Sikap Manusia. Jakarta : Bina Rupa.

Depkes RI. (2015). Pendekatan Epidemiologi dan Dasar-Dasar Survailans. Jakarta : Depkes RI.

Dwi Yani Bidaya, Titan Ligita, Meta Trissya. (2012). Hubungan Tingkat Pengetahuan Ibu dengan Perilaku
Pencegahan ISPA Pada Bayi di

Puskesmas Kecamatan Segedong.

Fakultas Kedokteran Universitas

Tanjungpura Pontianak

Herliansyah, Yudhi. 2006. Pengaruh

Pengalaman Terhadap Bukti Tidak

Relevan. Simposium Nasional 9.

Padang.http://info.stieperbanas.acid

Hidayat Azis Alimul. (2008). Riset Keperawatan dan Teknik Penulisan Ilmiah. Jakarta : Salemba Medika.

Intan Silviana. (2014). Hubungan Pengetahuan Ibu Tentang Penyakit ISPA dengan Perilaku Pencegahan ISPA pada Balita di PHPT ANGKE Jakarta Utara. Forum Ilmiah. September : Vol 11 No 3.

Nursalam. (2008). Konsep dan Penerapan Metodologi Penelitian Ilmu Keperawatan:Pedoman Skripsi dan Tesis dan Penyusunan Instrumen Penelitian Keperawatan. Jakarta : Salemba Medika.

Nursalam. (2008). Pendekatan Psikis Metodologi Riset Keperawatan. Jakarta : CV. Agung Seto.

Ngastiyah. (2012). Perawatan Anak Sakit. Jakarta : EGC.

Nelson, (2000). Ilmu Kesehatan Anak. Jakarta : EGC.

Notoatmodjo, Soekidjo (2015). Metodologi Penelitian Kesehatan. Jakarta : Rineka Cipta.

Soetjiningsih, (2014). Tumbuh Kembang Anak. Jakarta : EGC

Notoatmodjo, Soekidjo (2015). Pendidikan dan Perilaku Kesehatan. Jakarta : Rineka Cipta.

Sarwono, Solita. (2012). Sosiologi Kesehatan. Yogyakarta: Gadjah Mada University Press. 